Testy Psychologiczne w Praktyce i Badaniach, 2019, Numer specjalny, 2, 57-81, ISSN: 24499072

\author{
ALICJA CZEREDERECKA* \\ Instytut Ekspertyz Sądowych, Kraków
}

\title{
Tworzenie Standardów opiniowania psychologicznego w sprawach rodzinnych i opiekuńczych
}

\begin{abstract}
Zasadniczym celem standardów opiniowania psychologicznego w sprawach rodzinnych i opiekuńczych było stworzenie określonego algorytmu pracy ekspertów z zakresu psychologii sądowej, który ma stanowić pomoc w jak najlepszym wywiązywaniu się $\mathrm{z}$ powierzonych im zadań. Jednocześnie dokument może służyć ocenie poprawności opinii ich odbiorcom, którymi są zarówno zleceniodawcy (sądy), jak i opiniowani oraz reprezentanci ich interesów w postępowaniu przed sądem (np. adwokaci).

$\mathrm{W}$ artykule opisano historię powstawania standardów, osoby zaangażowane w ten proces oraz jego efekty. Przedstawione zostały także założenia teoretyczne oraz sposób rozstrzygnięcia dylematów, które pojawiały się na poszczególnych etapach powstawania tekstu.
\end{abstract}

The main objective of the standards of psychological evaluation in custody cases was to create a specific algorithm for the work of experts in forensic psychology, which is to assist in the best possible performance of their tasks. At the same time, the document may be used to assess the correctness of opinions of their recipients, which are both the clients (courts) and the respondents and representatives of their interests in court proceedings (e.g. lawyers).

The article describes the history of standards development, persons involved in this process and its effects. It also presents theoretical assumptions and the way of resolving dilemmas that appeared at each stage of the text's creation.

\section{Okoliczności podjęcia inicjatywy sformułowania standardów}

Przełom XX i XXI wieku można określić jako okres, w którym podejmowane są różne działania zmierzające do uporządkowania statusu zawodu psychologa: wymogów edukacyjnych, etycznych, a także zakresu kompetencji i zasad związanych z wykonywaniem pracy. Szczególny nacisk kładzie się na empiryczne podstawy wnioskowania oraz weryfikowalność ustaleń badawczych i diagnostycznych. Działania te podejmują stowarzyszenia psychologiczne (na szczeblach regionalnych, krajowych i międzynarodowych), ale także zrzeszenia stawiające sobie za cel badanie poprawności rezultatów dociekań i analiz specjalistów z różnych dziedzin, w szczególności tych, w których wnioskowanie narażone jest na subiektywizm (np. wynikający z niekontrolowanego wpływu relacji interpersonalnych pomiędzy badającym a badanym). Warto w tym miejscu wymienić zwłaszcza aktywność Amerykańskiego Towarzystwa Psychologicznego (American Psychological Association - APA) i Australijskiego Towarzystwa Psychologicznego

\footnotetext{
* Adres do korespondencji: Alicja Czerederecka, Instytut Ekspertyz Sądowych, Kraków, aczerederecka@ies.krakow.pl
} 
(Australian Psychological Association - APS) oraz odnoszące się bezpośrednio do naszego kraju działania Europejskiej Federacji Towarzystw Psychologów (European Federation of Psychologists' Associations - EFPA), które doprowadziły między innymi do powstania Europejskiego Dyplomu Psychologa (EuroPsy).

Wśród inicjatyw podejmowanych w XXI wieku w Polsce istotną rolę odegrały prace zmierzające do sformułowania certyfikatów lub licencji w różnych dziedzinach psychologii stosowanej, a w ostatnich latach także standardów pracy psychologa. Pierwszym takim działaniem było opublikowanie 21 czerwca 2014 r. Standardów diagnozy psychologicznej opracowanych przez Ogólnopolską Sekcję Diagnozy Psychologicznej Polskiego Towarzystwa Psychologicznego. Twórcy tych Standarów omówili je szczegółowo w jednym z rozdziałów książki „Diagnoza psychologiczna: kompetencje i standardy. Wybrane zagadnienia" (Paluchowski i in., 2015).

W zakresie psychologii sądowej w 2000 roku Sekcja Psychologii Sądowej podjęła prace nad ustaleniem zasad rekomendacji dla biegłych, które wprowadzono w 2002 r. (Jaśkiewicz, Czerederecka, 2005). Równolegle podobne rekomendacje opracowało Stowarzyszenie Psychologów Sądowych w Polsce. Ponadto w 2006 r. opublikowane zostały kryteria oceny dowodu z opinii psychologicznej autorstwa Alicji Czeredereckiej (Czerederecka, 2006), modyfikowane i uszczegóławiane w późniejszym okresie, także w odniesieniu do opinii w sprawach rodzinnych i opiekuńczych (Czerederecka 2013a, 2015).

Wskutek zachęt ze strony jednej z autorek Standardów diagnozy, Mai Filipiak, do tworzenia standardów $\mathrm{w}$ poszczególnych dziedzinach psychologii stosowanej Alicja Czerederecka podjęła decyzję o stworzeniu zespołu, który opracuje standardy z zakresu psychologii sądowej. Dyskusja w gronie biegłych sądowych, w której uczestniczyła także Przewodnicząca Polskiego Towarzystwa Psychologicznego, Małgorzata Toeplitz-Winiewska, doprowadziła do konkluzji, że w pierwszej kolejności standardy takie zostaną stworzone w odniesieniu do opiniowania dotyczącego problematyki rodzinnej i opiekuńczej. Złożyło się na to kilka powodów.

Po pierwsze, opracowanie zasad ogólnych jest zadaniem trudnym, a wskazówki w nich zawarte mogą się okazać niewystarczające i niesatysfakcjonujące dla psychologów opiniujących $\mathrm{w}$ różnych obszarach prawa. Jest to $\mathrm{z}$ jednej strony spowodowane różnorodnością badanej problematyki i przygotowaniem specjalistycznym praktyków (np. z zakresu psychologii klinicznej, rozwojowej dziecka itd.) ${ }^{1}$, z drugiej - korzystaniem z różnych

${ }^{1}$ Ta różnorodność wymaganych kwalifikacji sprawia, że rekomendacje dla biegłych psychologów sądowych przyznawane są w odniesieniu do różnych zakresów aktywności biegłego (rodzinnej i opiekuńczej, nieletnich, dorosłych sprawców przestępstw, sprawców 58 
źródeł informacji (od opinii dotyczących profilu psychologicznego sprawcy, które ograniczają się do analizowania akt sprawy, przez opinie dotyczące osób nieżyjących lub zaginionych, gdzie materiał zostaje, o ile to możliwe, rozszerzony o pośrednie dane pochodzące $\mathrm{z}$ wywiadów od innych osób oraz z wytworów opiniowanego, po te opinie, $\mathrm{w}$ których analizie poddawane są przede wszystkim wyniki bezpośredniego badania psychologicznego). Dlatego stwierdzono, że korzystniej będzie rozpocząc od tematyki szczegółowej.

Ponieważ problematyka rodzinno-opiekuńcza obejmuje szczególnie dużo wątków i wymaga kompetencji odnoszących się do wielu obszarów psychologii, obecnych także w innych obszarach opiniowania, uznano, iż można je będzie bezpośrednio do nich odnieść, ułatwi to także opracowanie specyficznych dla nich reguł postępowania w przyszłości. Ponadto ta różnorodność badanych problemów, jak i konieczność objęcia badaniem kilku osób (zwykle co najmniej trzech), wymaga opracowania złożonej strategii badawczej, w czym uporządkowane zasady postępowania mogą stanowić istotna pomoc.

Co więcej, potrzebę szczegółowych wytycznych zgłaszali coraz częściej praktycy zajmujący się rozstrzyganiem kwestii rodzinnych i opiekuńczych z perspektywy prawnej. Narastała też liczba zarzutów i skarg badanych rodziców w odniesieniu do przebiegu badań psychologicznych oraz do treści opinii z tego zakresu (i była znacznie większa niż w stosunku do innych typów opinii), a podejmowane analizy jakości tych opinii Czerederecka, 2013b; Ostaszewski, 2013) potwierdzały istnienie wielu nieprawidłowości.

Ostatni z wymienionych powodów przeważył o uznaniu szczególnie pilnej potrzeby sformułowania standardów dotyczących problematyki rodzinnej i opiekuńczej i o podjęciu się tego zadania w pierwszej kolejności. Ponadto uznano, że jeśli standardy pracy biegłego w obszarze wymagającym spełnienia wyjątkowo złożonych pod względem merytorycznym i etycznym warunków zostanie zrealizowany i powszechnie zaakceptowany, utoruje drogę do prac nad ogólnymi zasadami pracy biegłych i tymi, które będą specyficzne dla opiniowania w innych obszarach.

wypadków w pracy lub wypadków drogowych, nieznanych sprawców, problematyki cywilnej, uzależnień). 


\section{Osoby zaangażowane w powstawanie Standardów ${ }^{2}$ i etapy pracy}

Aby projekt uwzględniał różne warunki pracy osób opiniujących w sprawach rodzinnych i opiekuńczych oraz pozytywne doświadczenia wynikające z dotychczas funkcjonujących praktyk, powołany został zespół, który składał się z osób łączących prace naukowo-badawcze z praktyką biegłego, a zarazem reprezentujących różne środowiska w kraju i posiadających różny status prawny w opiniowaniu. W skład tego zespołu weszli: dr Magdalena Błażek i dr Aleksandra Lewandowska-Walter zatrudnione na Uniwersytecie Gdańskim i w Rodzinnym Ośrodku Diagnostyczno-Konsultacyjnym ${ }^{3}$ w Gdańsku; dr Justyna Trepka-Starosta i dr Agnieszka Roszkowska z Uniwersytetu Śląskiego, zajmujące się opiniowaniem jako biegłe sądowe z listy Sądu Okręgowego w Katowicach; dr Adrian Kurcbart z Uniwersytetu Jana Kochanowskiego w Kielcach, opiniujący jako biegły z listy Sądu Okręgowego w Kielcach; dr Małgorzata Toeplitz-Winiewska reprezentująca Uniwersytet Warszawski, Przewodnicząca Polskiego Towarzystwa Psychologicznego (PTP) odbierająca w imieniu PTP zarzuty i skargi na zawartość merytoryczną opinii biegłych; dr Maria Kujawa i Kamil Jezierski z Uniwersytetu Jagiellońskiego w Krakowie, reprezentujący Stowarzyszenie Psychologów Sądowych w Polsce (SPSP) i powoływani przez sąd jako biegli ad hoc. Koordynatorem prac i autorką projektu była dr Alicja Czerederecka z Instytutu Ekspertyz Sądowych, biegła Instytutu z zakresu psychologii. Do współpracy na różnych etapach włączali się również dr Tomasz Rajtar i dr Agnieszka Haś z Instytutu Ekspertyz Sądowych, także biegli Instytutu. Trzy spośród wyżej wymienionych osób posiadały rekomendacje (PTP), a dwie rekomendacje SPSP.

Roli konsultantów podjęli się: Maja Filipiak, Przewodnicząca Sekcji Diagnozy Psychologicznej Polskiego Towarzystwa Psychologicznego, dr hab. Danuta Rode reprezentująca Uniwersytet Humanistyczno-Społeczny SWPS, Wydział Zamiejscowy w

2 Określenie „Standardy” (pisane z dużej litery) będzie w tekście używane w zastępstwie pełnej nazwy dokumentu, tj. Standardów opiniowania psychologicznego w sprawach rodzinnych i opiekuńczych.

${ }^{3}$ Od 2016 r. instytucje te zostały przekształcone w opiniodawcze zespoły sądowych specjalistów (OZSS). Mają one opracowane wewnętrzne standardy metodologii opiniowania. Ich zawartość nie w pełni pokrywa się $\mathrm{z}$ tytułem (w niewielkim stopniu odnosi się do metodologii), ponieważ obejmuje głównie kwestie dotyczące zakresu zadań kierownika i specjalistów zatrudnionych $\mathrm{w}$ tych zespołach, wymienione na poziomie ogólnym etapy procesu diagnostycznego oraz zasady postępowania w przypadkach szczególnych i „schematy” opinii w sprawach rodzinnych i opiekuńczych oraz nieletnich. A zatem w zasadniczej większości są styczne ze Standardami opiniowania w sprawach rodzinnych i opiekuńczych i mogą (a raczej powinny) być traktowane komplementarnie (por. pełny tekst standardów OZSS wraz z komentarzami w: Domagała, Zamiela-Kamińska, 2016). 
Katowicach, Hanna Domagała z Ministerstwa Sprawiedliwości i Maria Zamiela-Kamińska z Rodzinnego Ośrodka Diagnostyczno-Konsultacyjnego $\mathrm{nr} 2 \mathrm{w}$ Warszawie, a ponadto prawnicy: dr Irena Kleniewska z Uczelni Łazarskiego w Warszawie oraz Izabela Strózik i Anna Witasik reprezentujące Sąd Okręgowy w Krakowie ${ }^{4}$.

Prace zostały podjęte w połowie 2015 r. Dwa pierwsze etapy, które przebiegały równolegle, obejmowały stworzenie wstępnego projektu oraz przygotowanie konferencji, w której zaplanowano omówienie zagadnień szczegółowych dotyczących standardów.

Konferencja odbyła się w dniach 4-5 grudnia 2015 r. w Krakowie i działania podjęte podczas jej trwania stanowiły drugi etap przygotowań. Wykładowcy - członkowie powołanego zespołu - przedstawili wstępny zarys standardów oraz indywidualną perspektywę dotyczącą zagadnień szczegółowych. Drugą część konferencji stanowiły warsztaty, których zasadniczym celem było wyznaczanie granic swobody decyzji biegłego w odniesieniu do kontrowersyjnych kwestii wyłonionych prze prowadzących, ale także uczestnicy zgłaszali dylematy pochodzące z własnej praktyki opiniodawczej. Dyskusje te odegrały istotną rolę w ukierunkowaniu pracy nad zagadnieniami szczegółowymi. Ponieważ w konferencji wzięli udział głównie praktycy reprezentujący zarówno zleceniodawców (sędziowie), pełnomocników stron (adwokaci), jak i biegłych sporządzających opinię, pozwoliło to zadbać o to, by przyjmowane zasady były zgodne z obowiązującymi przepisami prawnymi oraz by w ich ramach poszukiwać rozwiązań koncyliacyjnych, satysfakcjonujących tak dla odbiorców opinii, jak i biegłych, którzy je opracowują. Konferencja dostarczyła też pierwszych informacji zwrotnych na temat użyteczności Standardów dla praktyków.

Trzeci etap prac stanowiło wprowadzenie do zarysu projektu zaleceń wypracowanych podczas konferencji oraz kolejne poprawki wprowadzane przez członków zespołu dotyczące zarówno treści, jak i formy tekstu. Na tym etapie podjęto także decyzję o wyodrębnieniu w Standardach zagadnień ogólnych i szczegółowych, dodaniu załączników oraz stworzeniu komentarzy do standardów. Wprowadzane zmiany były przekazywane konsultantom. Uzgodnienia trwały tak długo, dopóki nie wypracowano wspólnego stanowiska. Prace te odbywały się w formie korespondencji elektronicznej, co pozwoliło na ich duże usprawnienie. Końcowy projekt był gotowy na początku marca, co oznacza, że pomimo dużej obszerności tekstu, opracowano go w cztery miesiące.

Czwarty etap prac stanowiło przekazanie tekstu do konsultacji środowiskowych, na które przeznaczono 3 tygodnie. Odzew był niewielki, ale zgłoszone uwagi pozwoliły wprowadzić jeszcze drobne poprawki i uzupełnienia. Ostatnie prace miały charakter redakcyjny i dotyczyły strony formalnojęzykowej tekstu.

\footnotetext{
${ }^{4}$ Miejsca zatrudnienia wszystkich wymienionych osób podane zostały w odniesieniu do
} 
Efektem tych działań było ogłoszenie Standardów opiniowania psychologicznego w sprawach rodzinnych i opiekuńczych w dniu 2 kwietnia 2016 r. Ponadto w październiku tego samego roku opublikowana została książka pod tym samym tytułem (Czerederecka, 2016). Zawiera ona rozdziały poświęcone podstawom prawnym sporządzania opinii w sprawach rodzinnych i kompetencjom biegłego psychologa $\mathrm{w}$ odniesieniu do tej problematyki; tekst Standardów oraz komentarze do niej (psychologiczny i prawny), a także zagadnienia szczegółowe dotyczące granic diagnozy (wyznaczonych tezami zawartymi w postanowieniu o powołaniu biegłego), doboru metod, zasad diagnozowania więzi uczuciowych w rodzinie $\mathrm{i}$ integrowania danych ilościowych oraz jakościowych. Odrębne rozdziały poświecono też problemowi opieki naprzemiennej, zasadom obowiązującym w procedurach adopcyjnych oraz standardom opiniowania obowiązującym w opiniodawczych zespołach sądowych specjalistów.

\section{Wykorzystane źródła}

Tworząc Standardy opiniowania w sprawach rodzinnych i opiekuńczych korzystano z literatury poświęconej ekspertyzie psychologicznej z tego obszaru, diagnozie i metodologii psychologicznej, zasadom etycznym pracy psychologa, diagnosty i biegłego. Wzorowano się też na istniejących już dokumentach: kodeksach, zaleceniach i standardach stworzonych dotychczas przez psychologów. W komentarzu psychologicznym istotne źródła odniesienia stanowiły też najnowsze publikacje i wytyczne dotyczące narzędzi stosowanych w diagnozie psychologicznej, np. Wytyczne Międzynarodowej Komisji ds. Testów. Obszerna lista tych źródeł została zamieszczona na końcu niniejszego tekstu. W tym miejscu należy jednak wymienić kilka pozycji, które odegrały kluczową rolę: Kodeks etyczno-zawodowy psychologa opracowany w 1991 r. przez Polskie Towarzystwo Psychologiczne, ale też Kodeks etyczny APA (utworzony w 1992 r., ostatnia modyfikacja z 2010 r.) oraz kilka innych dokumentów APA odnoszących się do psychologów sądowych: jeden stanowiący ogólne zalecenia dotyczące postępowania w tym obszarze (Specialty Guidelines for Forensic Psychology z 2012 r., modyfikacja wersji z 1992 r.) oraz dwa poświęcone specjalnie problematyce rodzinnej i opiekuńczej:, Guidelines for Child Custody Evaluations in Family Law Proceedings z 2009 r. (modyfikacja wersji z 1994 r.) i Guidelines for Psychological Evaluations in Child Protection Matters z 2012 r. (modyfikacja wersji z 1999 r.).

okresu, gdy pracowano nad projektem. 
Główny punkt odniesienia w tworzeniu tego tekstu stanowiły wspomniane wyżej Standardy diagnozy opracowane w $2014 \mathrm{r}^{5}$. Zastosowano analogiczną konstrukcję, opartą na etapach pracy diagnostycznej, wychodząc z założenia, że ułatwi to odbiorcom uzupełniające korzystanie z obu dokumentów bez powielania zawartych w nich treści. Niemniej tematyka $i$ zakres poszczególnych problemów poruszanych w punktach szczegółowych obu dokumentów nie w pełni się pokrywa, toteż w tych miejscach, gdzie odniesienia były bezpośrednie, dla ułatwienia zostało to zaznaczone w nawiasach w poszczególnych punktach powstającego dokumentu ${ }^{6}$.

Podczas pracy nad Standardami przedmiotem największych dyskusji były dwie kwestie:

- poziom szczegółowości omawianych problemów,

- stopień kategoryczności ich formułowania, zaczynając od samej nazwy (standardy, zalecenia, czy wskazówki?) po niektóre określenia specyficzne zawarte w tekście.

Efektem tej dyskusji było przyjęcie bardziej kategorycznej formy w odniesieniu do nazwy dokumentu, uznając tym samym, że jego tekst będzie się koncentrował na pryncypiach (obowiązkach), zaś bardziej szczegółowe zagadnienia, wskazówki aplikacyjne, zalecenia i sugestie dotyczące działania biegłego o znacznym marginesie swobody zostaną ujęte w załącznikach oraz komentarzach do tekstu.

W głównym tekście standardów wyodrębniono zagadnienia ogólne odwołujące się do postawy biegłego psychologa wobec wypełniania swojej roli w kontekście wypowiadania się o kwestiach rodzinnych i opiekuńczych oraz zasady postępowania w kolejnych etapach opracowywania opinii.

Warto zaznaczyć, że wiele zagadnień zawartych w Standardach odnosi się do opiniowania psychologicznego w ogóle, a znaczna część może być z powodzeniem wykorzystana w odniesieniu do innych zagadnień szczegółowych niż problematyka rodzinna i opiekuńcza. Dotyczy to zwłaszcza tych kwestii, w rozstrzygnięciu których podstawą diagnozy jest badanie konkretnych osób (czyli w sytuacjach, gdy podmiot opiniowania jest potencjalnie dostępny). W przyszłości, gdy powstaną nadrzędne standardy opiniowania psychologicznego, zagadnienia ogólne zostaną wyłączone ze standardów rodzinnych i opiekuńczych z uwzględnieniem odpowiednich modyfikacji (niektóre pojęcia zostaną sformułowane na

${ }^{5}$ Wykorzystywano obowiązującą wówczas pierwszą wersję Standardów diagnozy. Z chwilą pisania tego tekstu punkt odniesienia stanowiła nowelizacja Standardów diagnozy psychologicznej z 17 lutego $2018 \mathrm{r}$.

${ }^{6} \mathrm{Na}$ przykład punkt 1.1. zagadnień szczegółowych pozostaje w ścisłym związku $\mathrm{z}$ zagadnieniami punktów 1.1. i 1.2. Standardów diagnozy psychologicznej, a punkt 1.2. stanowi (częściowo) odpowiednik punktu o tym samym numerze (1.2.) Standardów diagnozy psychologicznej. 
bardziej ogólnym poziomie, np. termin „sąd” zostanie zastąpiony słowem „zleceniodawca” itp.).

\section{Funkcja Standardów}

Należy podkreślić, że Standardy nie mają mocy prawnej. Powinno się je traktować jako wytyczne do postępowania psychologa zajmującego się opiniowaniem. Stanowią też wskazówki dla odbiorców opinii (tak zleceniodawców, jak i badanych osób, czego mogą, a czego powinni oczekiwać, co leży w zakresie kompetencji psychologa, jaki jest cel podejmowanych przez niego działań, jakie są uprawnienia osoby badanej i jakie potencjalne konsekwencje niepodejmowania współpracy $\mathrm{z}$ badającym. Tym samym dostarczają odpowiedzi na podstawowe pytania i wątpliwości dotyczące tego, czy biegły opracowywał opinię zgodnie z zasadami sztuki i do formułowania zarzutów, jeśli postępowanie biegłego było niezgodne ze standardami. Przede wszystkim zaś standardy powinny stanowić wskazówki dla sądu, czy, a jeśli tak, to w jakim zakresie istnieją podstawy do podawania w wątpliwość opinii biegłego. Jednocześnie dokument ten powinien być pomocny dla eksperta $\mathrm{w}$ formułowaniu odpowiedzi na zarzuty postawione w odniesieniu do jego opinii - zarówno przed sądem, jak i przed komisjami powołanymi w środowisku zawodowym.

Trzyletni okres funkcjonowania standardów nie napawa optymizmem. Pokazuje, że liczba zarzutów dotyczących opinii nadal wzrasta; sądy rzadko selekcjonują je, zazwyczaj w całości przesyłają biegłym oczekując ustosunkowania się. Zainteresowanie Standardami ogranicza się do dosyć zamkniętego grona biegłych i prawników, wielu praktyków nie ma świadomości ich istnienia lub zna je niezwykle powierzchownie. Istnieją jednak także zauważalne oczekiwane korzyści - praktycy ujawniający rozterki związane z zasadami postępowania biegłych podkreślają, że dokument ten, podobnie jak komentarze do niego, stanowią dla nich istotną pomoc i ułatwiają doskonalenie warsztatu pracy.

\section{Literatura i dokumenty cytowane}

APA (2010): Ethical Principles of Psychologists and Code of Conduct.

APA (2010) Guidelines for Child Custody Evaluations in Family Law Proceedings.

APA (2013) Guidelines for Psychological Evaluations in Child Protection Matters.

APA (2013) Specialty Guidelines for Forensic Psychology.

Czerederecka, A. (2015). Kryteria oceny dowodu z opinii psychologicznych w sprawach rodzinnych i opiekuńczych. W: M. Filipiak, W. J. Paluchowski, B. Zalewski, M. Tarnowska 
(red.) Diagnoza psychologiczna: kompetencje i standardy. Wybrane zagadnienia (200-227).

Warszawa: Pracownia Testów Psychologicznych.

Czerederecka, A. (2013a). Kryteria oceny dowodu z opinii biegłego psychologa. Problems of Forensic Sciences, 93, 333-350.

Czerederecka, A. (2013b). Rodzinne ośrodki diagnostyczno-konsultacyjne na cenzurowanym. Rodzina i Prawo, 24, 17-27.

Czerederecka A. (red.). (2016). Standardy opiniowania psychologicznego w sprawach rodzinnych i opiekuńczych. Kraków: Wydawnictwo Instytutu Ekspertyz Sądowych.

Czerederecka, A. (2006). Test Rorschacha w psychologicznej ekspertyzie sadowej.

Wykorzystanie systemu Exnera. Kraków: Wydawnictwo Instytutu Ekspertyz Sądowych, s. 267-276.

Domagała, H., Zamiela-Kamińska, M. (2016). Standardy opiniowania w opiniodawczych zespołach sądowych specjalistów. W: A. Czerederecka (red.). Standardy opiniowania psychologicznego w sprawach rodzinnych i opiekuńczych (303-331). Kraków: Wyd. IES.

Jaśkiewicz, T., Czerederecka, A. (2005). Rekomendacje dla biegłych psychologów - doraźna propozycja czy rozwiązanie problemu? (W:) Biegly w sadzie. Materiały z konferencji w 40. Rocznicę śmierci prof. J. Sehna (s. 135-142). Kraków: Wydawnictwo IES.

Paluchowski, W. J., Tarnowska M., Filipiak M. (2015). Standardy diagnozy psychologicznej. (W): M. Filipiak, W. J. Paluchowski, B. Zalewski, M. Tarnowska (red.), Diagnoza psychologiczna: kompetencje i standardy (s. 200-227). Warszawa: Pracownia Testów Psychologicznych.

\section{Literatura i dokumenty wykorzystane do opracowania tekstu (oprócz wyżej wymienionych)}

Ackerman, M. J. (2006). Clinicin's guide to custody evaluation. New York: Wiley \& Sons.

Ackerman, M. J. (2005). Podstawy psychologii sądowej, Gdańsk: Gdańskie Wydawnictwo Psychologiczne.

AERA, APA, NCME: American Educational Research Association, American Psychological Association, National Council on Measurement in Education (2007). Standardy dla testów stosowanych w psychologii i pedagogice. Gdańsk: Gdańskie Wydawnictwo Psychologiczne.

APA (2013) Guidelines for the Practice of Parenting Coordination.

Bowlby, J. (2007). Przywiązanie. Warszawa: PWN.

Brzeziński, J. (2009). Kiedy odwołując się do testów psychologicznych postępujemy nieetycznie? Analiza kontekstu psychometrycznego. Czasopismo Psychologiczne, 15(2), 321-332.

Brzeziński, J. (2009). Kiedy odwołując się do testów psychologicznych postępujemy nieetycznie? Analiza kontekstu psychometrycznego. Czasopismo Psychologiczne, 15, 321-332.

Brzeziński, J. (2004). Metodologia badań psychologicznych. Warszawa: PWN. 
Brzeziński, J. (2000). Problemy etyczne badań naukowych i diagnostycznych. (W:) J. Strelau (red.). Psychologia. Podręcznik akademicki, t. I. (s. 523-538). Gdańsk: Gdańskie Wydawnictwo Psychologiczne.

Brzeziński, J., Toeplitz-Winiewska (red.). (2004). Praktyka psychologiczna w świetle standardów etycznych. Warszawa: Wydawnictwo WSPS „Academica”.

Cierpiałkowska, L., Sęk, H. (2015). Wyzwania dla psychologii klinicznej XXI wieku. Nauka. Kwartalnik PAN, 2, 69-85.

Collier, H. L. (1996). The analysis of family dynamics in child custody cases. W: G. Davies i in. (red.), Psychology, Law and Criminal Justice (s. 231-239). Berlin: Walter de Gruyter.

Czerederecka, A. (2010a). Opiniowanie psychologiczne a postępowanie z rodzinami uwikłanymi w silny konflikt dotyczący uregulowania władzy rodzicielskiej. (W:) B. Gulla, I. Niewiadomska, M. Wysocka-Pleczyk, (red.), Białe plamy w psychologii sadowej (s. 59-69). Kraków: Wydawnictwo Uniwersytetu Jagiellońskiego.

Czerederecka, A. (2013c). Rozstrzyganie o kwestiach związanych ze sprawowaniem władzy rodzicielskiej i uregulowaniem kontaktów z dziećmi - refleksje psychologa. Rodzina i Prawo, 26/27, 87-96.

Czerederecka, A. (2010b). Rozwód a rywalizacja o opiekę nad dziećmi. Warszawa: LexisNexis.

Czerederecka, A., Gierowski, J. K., Jaśkiewicz-Obydzińska, T. (2007). Ekspertyza psychologiczna. W: M. Kała, D. Wilk, J. Wójcikiewicz (red). (red.), Ekspertyza sądowa. Zagadnienia wybrane (s. 387-436). Warszawa: Wolters Kluwer.

Czerederecka, A., Gierowski J. K., Paprzycki L. K. (2014). Ujawnianie wyników surowych z badań psychologicznych. (W:) E. Habzda-Siwek, J. Kabzińska (red.), Psychologia i prawo. Między teoria a praktyka (s. 318-336). Sopot: Gdańskie Wydawnictwo Psychologiczne.

Dana, R. H., Aguilar-Kitibutr, A., Diaz-Vivar, N. Vetter, H. (2002). A teaching method for multicultural assessment: Psychological report contents and cultural competence. Journal of Personality Assessment, 79(2), 207-215.

Dzierżanowska, J., Studzińska, J. (2015). Kryteria oceny dowodu z opinii biegłego w orzecznictwie Sądów Powszechnych i Sądu Najwyższego. Roczniki Nauk Prawnych, 25(2), $21-47$.

Earl, K. (2004). Psychological assessment in the changing climate of family law. W: A. Czerederecka, T. Jaśkiewicz-Obydzińska, R. Roesch, J. Wójcikiewicz (red.), Forensic Psychology and Law. Facing the challenges of a changing world (337-345). Kraków: Wydawnictwo IES.

Fabricius, W., Diaz, P., Braver, S. (2011). Parenting time, parent conflict, parent-child relationships, and children's physical health. (W:) K. Kuehnle, L. Drozd (red.), Paerenting plan evaluations. Applied research for Family Court (s. 188-213). New York: Oxfford University Press.

Flens, J. (2005). The responsible use of psychological testing in child custody evaluations. Selection of tests. Journal of Child Custody, 2(1/2), 3-29.

Galatzer-Levy, R., Kraus, L, Galatzer-Levy, J. (2009). The scientific basis of child custody decisions. Hoboken: Wiley. 
Garber, B. (2009). Attachment methodology in custody evaluation: four hurdles standing between developmental theory and forensic application. Journal of Child Custody, 6, 38-61.

Gierowski, J. K. (2015). Opinowanie sądowo-psychologiczne. (W:) M. Filipiak, W. J. Paluchowski, B. Zalewski., M. Tarnowska (red.), Diagnoza psychologiczna: kompetencje $i$ standardy (s. 167-198). Warszawa: Pracownia Testów Psychologicznych.

Gould, J., Martindale, D. (2007). The art and science of child custody evaluations. New York: Guilford Press.

Haak, H. (1995). Władza rodzicielska: komentarz. Toruń: Towarzystwo Naukowe Organizacji i Kierownictwa „Dom Organizatora”.

Haney-Caron, E., Heilbrun, K. (2014). Lesbian and Gay Parents and Determination of Child Custody: The Changing Legal Landscape and Implications for Policy and Practice.

Psychology of Sexual Orientation and Gender Diversity, 1, 19-29.

Hodges, W. (1991). Intervention for children of divorce. Custody, access, and psychotherapy. New York: John Wiley and Sons.

Hornowska, E., Paluchowski, W. J. (2004). Kulturowa adaptacja testów psychologicznych. (W:)]J. Brzeziński (red.), Metodologia badań psychologicznych. Wybór tekstów (s. 151-191). Warszawa: Wydawnictwo Naukowe PWN.

Hynan, D. J. (2013). Assessing parenting in child-custody evaluation: Use of the Parent-Child Relationship Inventory. Open Access Journal of Forensic Psychology, 5, 182-198.

Kalmbach, K., Lyons, P. (2006). Ethical issues in conducting forensic evaluations. Applied Psychology in Criminal Justice, 2, 261-290.

Kardas, P. (2014). Pozaprocesowe czynności obrońcy a tzw. dowody prywatne w świetle nowelizacji procedury karnej. Palestra, 9, 119-136.

Kuehnle, K., Drozd, L. (2012) (red.). Paerenting plan evaluations. Applied research for Family Court. New York: Oxfford University Press.

Matsumoto, D., Juang, L. (2007). Psychologia międzykulturowa. Gdańsk: Gdańskie Wydawnictwo Psychologiczne.

Melton, G., Petrila, J., Poythers, N., Slobogin, C. (2007). Psychological valuations for the courts: A handbook for mental health professionals and lawyers. New York: Gilford Press.

Ostaszewski, P. (2013). Opinie sporządzane przez rodzinne ośrodki diagnostycznokonsultacyjne w sprawach opiekuńczych i rozwodowych. E. Holewińska-Łapińska (red.). Prawo w Działaniu, 14. Sprawy cywilne (s. 7-25). Warszawa: Instytut Wymiaru Sprawiedliwości.

Otto, R., Edens, J., Barcus, E. (2000). The use of psychological testing in child custody evaluations. Family and Conciliation Courts Review, 38, 312-340.

Paluchowski, W. J. (2010). Diagnoza oparta na dowodach empirycznych (EBP) - Czy potrzebny jest polski „Buros”? Roczniki Psychologiczne, 13, s. 7-27.

Paluchowski, W. J. (2015). Kompetencje diagnostyczne psychologów. (W): M. Filipiak, W. J. Paluchowski, B. Zalewski, M. Tarnowska (red.), Diagnoza psychologiczna: kompetencje $i$ standardy (s. 200-227). Warszawa: Pracownia Testów Psychologicznych. 
Plopa, M. (2005). Psychologia rodziny. Teoria i badania. Kraków: Wydawnictwo Impuls.

Radwański, Z. (1981). Pojęcie i funkcja „dobra dziecka” w polskim prawie rodzinnym i opiekuńczym, Studia Cywilistyczne, 31, 5-21.

Sokołowska, A. (1977). Psychologiczna ekspertyza sądowa w sprawach dzieci i młodzieży. Warszawa: PWN.

Spring, B. (2007). Evidence-based practice in clinical psychology: What it is, why it matters; what you need to know. Journal of Clinical Psychology, 63, 611-632.

Stahl, P. (2014). Conducting Child Custody and Parenting Evaluations. (W:) I. Weiner, R. Otto (red.), The Handbook of Forensic Psychology (s. 137-170). New York: John Willey Eds.

Stemplewska-Żakowicz, K. (2011). Diagnoza psychologiczna. Diagnozowanie jako kompetencja profesjonalna. Gdańsk: Gdańskie Wydawnictwo Psychologiczne.

Stemplewska-Żakowicz, K., Paluchowski, W. J. (2013a). The reliability of projective techniques as tools of psychological assessment. Part 1: Why it is unjustified to describe some of them as projective? Problems of Forensic Sciences, 93, 421-437.

Stemplewska-Żakowicz, K., Paluchowski, W. J. (2013b). The reliability of projective techniques as tools of psychological assessment. Part 2: The Tree Test. Problems of Forensic Sciences, 94, 502-516.

Stojanowska, W. (red.). (2011). Nowelizacja prawa rodzinnego na podstawie ustaw z 6 listopada 2008 r. i 10 czerwca 2010 r. Analiza-wyktadnia-komentarz. Warszawa: LexisNexis.

Szustrowa, T. (2003). Raport o stanie orzecznictwa psychologicznego w Polsce. Warszawa: PTP.

Szymusik, A. (1996). Opinia kompleksowa - zakres kompetencji poszczególnych specjalistów. (W:) A. Głazek (red.), Dowód z opinii bieglego w projekcie kodeksu postepowania karnego (s. 27-34). Kraków: Wydawnictwo Instytutu Ekspertyz Sądowych.

The European Psychologist in Forensic Work and as Expert Witness. Recommendations for an ethical practice. (1997). (Pobrane z:) http://ethics.efpa.eu/guidelines/

Tomalski, P. (2007). Nietypowe rodziny. O parach lesbijek i gejów oraz ich dzieciach. Warszawa: Wydawnictwo Uniwersytetu Warszawskiego.

Tryjarska, B. (2012). Style przywiąania partnerów a tworzenie bliskich zwiazków w dorosłości. (W:) B. Tryjarska (red.), Bliskość w rodzinie. Więzi w dzieciństwie a zaburzenia w dorosłości (s. 185-217). Warszawa: Wydawnictwo Naukowe Scholar.

Ustawa z dnia 9 lipca 2015 r. o opiniodawczych zespołach sądowych specjalistów.

Weiner, I., Hess (2014). Practicing ethical forensic psychology. (W:) I. Weiner, R. Otto (red.), The handbook of forensic psychology (s. 85-110). Hoboken: John Willey \& Sons.

Widła, T. (2007). Metodyka ekspertyzy. (W:) J. Wójcikiewicz (red.), Ekspertyza sądowa. Zagadnienia wybrane (s. 387-436). Warszawa: Wolters Kluwer. 
Wytyczne Międzynarodowej Komisji ds. Testów (International Test Commission - ITC) z 2000 r. dotyczace stosowania testów (2000). Przygotował D. Bartram. Wersja polska w thumaczeniu T. Szustrowej autoryzowana przez Polskie Towarzystwo Psychologiczne.

Zalewski, B., Tarnowska, M., Filipiak, M. (2015). Proces profesjonalizacji zawodu psychologa w Polsce. (W): M. Filipiak, W. J. Paluchowski, B. Zalewski, M. Tarnowska (red.) Diagnoza psychologiczna: kompetencje $i$ standardy (s. 200-227). Warszawa: Pracownia Testów Psychologicznych. 


\section{Standardy opiniowania psychologicznego $\mathrm{w}$ sprawach rodzinnych i opiekuńczych}

\section{UWAGI OGÓLNE}

1. Podejmując się opiniowania dla potrzeb i na zlecenie wymiaru sprawiedliwości, psycholog traktuje jako pierwszoplanowe zasady zawodowego kodeksu etycznego dotyczące relacji z osobami, które dostarczają informacji o problemach wymagających rozstrzygnięcia z punktu widzenia wymiaru sprawiedliwości. Biegły psycholog przywiązuje szczególną wagę do podmiotowego traktowania tych osób. W trakcie całego procesu diagnostycznego:

a) dba o to, by pozyskać świadomą zgodę osób badanych na uczestniczenie w nim o tyle, o ile jej możliwości na to pozwalają; szczególną opieką otacza te osoby, które ze względu na dyspozycje indywidualne, dysfunkcje lub poziom rozwoju psychicznego nie są w stanie w pełni świadomie uczestniczyć we wszystkich czynnościach diagnostycznych *;

b) dąży do minimalizowania potencjalnych negatywnych konsekwencji uczestniczenia osób badanych w czynnościach diagnostycznych, a jeśli to nie jest możliwe - odstępuje od tych czynności lub od przeprowadzenia badania;

c) przywiązuje szczególną wagę do zachowania obiektywizmu, niekierowania się uprzedzeniami, uwzględniania kontekstu kulturowego i środowiskowego, uwzględnia prawo osób badanych do wygłaszania indywidualnych postaw i poglądów.

2. Biegły psycholog ponosi odpowiedzialność za poprawność metodologiczną sporządzanej opinii.

3. W sprawach rodzinnych i opiekuńczych wartością nadrzędną jest rozpatrywanie problemów wskazanych przez sąd z perspektywy zaspokojenia potrzeb indywidualnych i rozwojowych dziecka (psychologicznych aspektów pojęcia, które w kodeksie rodzinnym i opiekuńczym formułowane jest jako dobro dziecka). Oznacza to, że w wypadku konfliktu pomiędzy potrzebami i oczekiwaniami rodziców lub innych osób zaangażowanych w wychowanie i pielęgnację dziecka a dobrem dziecka psycholog kieruje się dobrem dziecka. Stara się jednak przedstawić informacje w taki sposób, by także pozostałe osoby uczestniczące w badaniu zrozumiały i uwzględniły tę perspektywę.

4. Psycholog podejmuje się roli biegłego w sprawach rodzinnych i opiekuńczych tylko wtedy, kiedy posiada wystarczające kompetencje i stale aktualizuje swoją wiedzę z zakresu:

- diagnozowania dorosłych i dzieci,

- problematyki wychowawczej i rozwojowej,

\footnotetext{
${ }^{*}$ Szerzej w odniesieniu do poszczególnych etapów badania: St. 3.2 i 4.3 . 
- problematyki małżeńskiej i życia w rodzinie, roli każdego z rodziców w procesie wychowawczym, zjawisk charakterystycznych dla sytuacji rozstania rodziców i uwikłania w postępowanie sądowe,

- podstaw psychologii klinicznej,

- podstawowej znajomości przepisów prawnych z tego zakresu.

5. Rozpatrując kwestie związane z sytuacjami dotyczącymi spraw rodzinnych i opiekuńczych, psycholog uwzględnia ich specyfikę, w szczególności następujące zjawiska:

- trudności w znalezieniu takiego rozwiązania, które byłoby satysfakcjonujące dla wszystkich zainteresowanych,

- opór badanych wobec ingerowania w ich życie intymne i wobec upubliczniania go,

- sprzeciw rodziców wobec oceniania ich kompetencji wychowawczych,

- brak krytycyzmu badanych w ocenie popełnianych błędów jako konsekwencja przeżywanego kryzysu psychologicznego - silne zaangażowanie emocjonalne $\mathrm{w}$ sytuację i obrona percepcyjna prowadząca do nieuznawania potrzeby zmian $\mathrm{w}$ swoim zachowaniu,

- silne napięcia pomiędzy rodzicami a sądem i jego przedstawicielami (w krąg których włączani są biegli),

- powoływanie się rodziców na prawa jednostki do realizowania własnego światopoglądu i na działanie w imię dobra dziecka,

- trudności w zachowaniu dystansu i obiektywizmu przez biegłych.

6. $\mathrm{Z}$ tego względu proces diagnostyczny powinien być przeprowadzany $\mathrm{w}$ zespole co najmniej dwuosobowym, a biegli powinni konsultować i poddawać superwizji swoje opinie. Jednocześnie każdy biegły ponosi indywidualną odpowiedzialność za treści zawarte w opinii, którą sporządził i pod którą złożył podpis.

7. $\mathrm{W}$ odniesieniu do przysposobienia dziecka (art. 114-124 k.r.o.) zaproponowano procedurę postępowania, w której opinia kwalifikacyjna opracowywana dla sądu stanowi jeden $\mathrm{z}$ etapów postępowania. Co do samego opiniowania pracowników ośrodków adopcyjnych, obowiązują niniejsze standardy.

\section{Zagadnienia szczególowe}

\section{Decyzja o sporzadzeniu opinii}

1.1. Sformułowanie problemów psychologicznych (odpowiednik St. dgn*. 1.1. i 1.2.)

Biegły analizuje przedmiot i zakres opinii wskazany w postanowieniu sądu pod kątem ustalenia, czy zawarte $\mathrm{w}$ nich problemy można rozstrzygnąć $\mathrm{z}$ wykorzystaniem wiedzy psychologicznej. Biegły musi brać pod uwagę, że badanie odbywa się zwykle w innych

\footnotetext{
${ }^{*}$ Standardy diagnozy psychologicznej, 17.02.2018 (St. dgn.).
} 
warunkach i czasie niż te, których dotyczą problemy wskazane w postanowieniu sądu Biegły uwzględnia te utrudnienia formułując pytania badawcze.

\subsection{Rozważenie dostępu do źródeł informacji (St. dgn. 1.2.)}

Biegły rozważa, czy udostępniony przez zleceniodawcę materiał oraz badanie wskazanych przez niego osób pozwoli udzielić odpowiedzi na sformułowane pytania. W wypadku negatywnej odpowiedzi podejmuje negocjacje ze zleceniodawcą w kierunku uzyskania dodatkowych materiałów lub rozszerzenia (zawężenia) kręgu osób badanych. W sprawach rodzinnych i opiekuńczych często zachodzi potrzeba zbadania dodatkowych osób uczestniczących w opiece, uzyskania dostępu do akt innych spraw, w których udział brali lub biorą uczestnicy badania, sprawozdań kuratorów, wywiadów środowiskowych itp.

\subsection{Rozważenie dostępu do narzędzi badawczych (St. dgn. 1.2.)}

Biegły zapoznaje się z aktami sprawy pod kątem ustalenia, czy dostępne mu narzędzia psychologiczne będą wystarczające do udzielenia odpowiedzi na pytania sformułowane przez sąd (zleceniodawcę).

\subsection{Rozważenie własnych kompetencji do rozstrzygnięcia problemu (St. dgn. 1.3; 1.8.)}

Biegły rozważa, czy kompetencje zawodowe, jakimi dysponuje, są wystarczające do rozstrzygnięcia badanego problemu, czy wymaga on pracy zespołowej biegłych tej samej, czy też różnych specjalności. Opinia opracowywana przez zespół co najmniej dwuosobowy powinna stanowić zasadę w sprawach rodzinnych i opiekuńczych. W wypadku decyzji o pracy zespołowej biegłych reprezentujących różne specjalności zakres odpowiedzialności każdego z biegłych zostaje jednoznacznie sformułowany. W wypadku wątpliwości diagnostycznych biegły korzysta z konsultacji lub superwizji innych specjalistów.

1.5. Rozważenie wątpliwości etycznych dotyczących podjęcia decyzji o przeprowadzeniu badań (St. dgn. 1.3., 1.10.)

Biegły analizuje otrzymane zlecenie pod kątem konfliktu ról związanego z innymi formami relacji z osobami badanymi (np. terapeuta, doradca, konsultant, mediator), własnymi przekonaniami wpływającymi na brak możliwości przyjmowania alternatywnych hipotez badawczych lub innych problemów etycznych, które zakłócałyby w sposób istotny obiektywizm sporządzenia opinii. Pozostawanie $w$ innych formach relacji $\mathrm{z}$ badanym wyklucza możliwość podjęcia się roli biegłego. Pozostałe czynniki, które mogą zakłócać obiektywizm biegłego, wymagają indywidualnego rozważenia odpowiedzialności etycznej.

1.6. Rozważenie możliwości realizacji zadania w oczekiwanym przez zleceniodawcę terminie

Biegły ustala, czy wywiązanie się $\mathrm{z}$ terminu wykonania opinii wskazanego przez zleceniodawcę jest możliwe. Jeśli nie, podejmuje negocjacje dotyczące terminu zadowalającego obie strony.

\subsection{Przyjmowanie opinii do realizacji}

Decyzja o podjęciu wykonania opinii następuje w wypadku pozytywnych odpowiedzi na wszystkie pytania dotyczące kwestii rozważanych w punktach 1.1.-1.4. i 1.6. oraz braku wątpliwości etycznych rozważanych w p. 1.5. W wypadku odpowiedzi negatywnej w 
odniesieniu do którejkolwiek kwestii rozważanych w p. 1.1.-1.4., 1.6. lub potwierdzenia przeciwwskazań wymienionych w p. 1.5., biegły odmawia wykonania opinii, przedstawiając zleceniodawcy przyczyny tej odmowy (St. dgn. 1.1., 1.8.). W takim wypadku biegły może (jeśli dysponuje taką wiedzą) zaproponować zleceniodawcy innych specjalistów, którzy byliby w stanie podjąć się wyznaczonych zadań (St. dgn. 1.5. i 1.6.). Jeśli biegły uważa, że zlecone mu zadania są niewykonalne, formułuje i uzasadnia taką opinię w piśmie do sądu.

1.8. Wprowadzanie zmian dotyczących zakresu opinii

W każdym wypadku, gdy biegły dostrzega potrzebę zmian dotyczących zakresu opinii (badanych problemów lub osób, lub materiałów źródłowych - np. dokumentacji leczenia) uzasadnione z punktu widzenia użyteczności dla prowadzonej sprawy, swoje propozycje kieruje do sądu i realizuje wyłącznie w wypadku jednoznacznej akceptacji w formie rozszerzonego postanowienia (por. St. dgn. 1.1.).

\section{Planowanie badań}

2.1. Formułowanie hipotez badawczych i rozważanie zakresu informacji niezbędnej do ich zweryfikowania (St. dgn. 2.1.-2.4.)

Biegły analizuje materiał dostępny w aktach sprawy pod kątem problemów i pytań badawczych zawartych w postanowieniu sądu, a następnie formułuje hipotezy badawcze dostosowane do analizowanej sytuacji i rozważa, jakie informacje powinien zgromadzić, by je zweryfikować. W sprawach dotyczących sytuacji rodzinnej biegły zwraca w szczególności uwagę na takie kwestie, jak czas trwania procesu i jego przebieg; osoby zaangażowane w wychowanie małoletnich; formy i charakter problemów występujących w rodzinie; zmiany, jakie zachodziły $\mathrm{w}$ opiece nad dziećmi; deklaracje opiekunów na temat sytuacji wychowawczej dzieci; treść dokumentacji dotyczącej zdrowia i sytuacji (przed)szkolnej dzieci; inne postępowania cywilne i karne, w których uczestniczą osoby badane.

\subsection{Planowanie czasu badania}

W sprawach rodzinnych i opiekuńczych wskazane jest wyznaczenie minimum dwóch spotkań. Biegły planuje terminy badań oraz tempo pracy, w których możliwe będzie zrealizowanie procedur diagnostycznych $\mathrm{w}$ warunkach czasowych, jakimi sam dysponuje i w taki sposób, by zapewnić komfort psychiczny osób badanych. Uwzględnia warunki obiektywne (np. możliwości dojazdu, kwestie finansowe i czasowe z tym związane) oraz subiektywne, tj. pochodzące od osób badanych (np. ich podatność na zmęczenie, odporność na stres, postawę wobec badania). W wypadku badania obejmującego kilka osób niezbędne jest optymalne zaplanowanie kolejności ich przybycia.

\subsection{Przygotowanie miejsca badania (St. dgn. 3.1.)}

Miejsce badania musi spełniać podstawowe warunki gabinetu psychologicznego sprzyjające skupieniu, a zarazem zapewniające poczucie bezpieczeństwa i podstawy komfortu psychicznego, a także izolację od osób niezaangażowanych w diagnozę. W wypadku badania opiekunów z dziećmi (lub osobami niepełnosprawnymi) mogą oni pozostawać w tym samym 
pomieszczeniu tylko wówczas, kiedy badana jest ich wzajemna relacja. W trakcie badań indywidualnych żaden z pozostałych członków rodziny nie może być obecny. Badani nie mogą zgłaszać się na spotkanie w towarzystwie innych osób, które nie mają być objęte badaniem w wyznaczonym terminie.

\subsection{Przygotowanie narzędzi badawczych}

Biegły decyduje o doborze narzędzi diagnostycznych $i$ ponosi za to pełną odpowiedzialność. Zwraca uwagę, by narzędzia badawcze w wysokim stopniu spełniały wymagania diagnostyczne (St. dgn. 2.5-2.9.). Ponadto dobiera je w taki sposób, by były w stanie zweryfikować postawione hipotezy, a zarazem, by uwzględniały możliwości osób badanych, ich postawę wobec badania (St. dgn. 1.5.), a także kompetencje badającego. Biegły uwzględnia ograniczenia czasowe, dbając jednocześnie o to, by potencjalne wyniki poszczególnych narzędzi pozwalały na wzajemne uzupełnianie się i weryfikację, a charakterystyka badanych i relacji między nimi była wielostronna. W planowanym zestawie metod badawczych biegły uwzględnia też metody alternatywne na wypadek, gdyby pierwszoplanowe nie spełniły swojej roli z jednego z wyżej wymienionych względów lub gdyby badany nie zgodziłby się na ich wykonanie. W wypadku badań porównawczych (np. kompetencji wychowawczych osób ubiegających się o sprawowanie pieczy nad dzieckiem) biegły stara się, o ile to możliwe, zastosować te same narzędzia i te same zestawy pytań w wywiadzie w odniesieniu do porównywanych osób.

2.5. Weryfikacja przedmiotu i zakresu opinii w przypadku niezgłoszenia się osób wskazanych $\mathrm{w}$ postanowieniu

Jeśli co najmniej jedna z osób wskazanych w postanowieniu sądu nie zgłosi się na badania lub nie wyrazi zgody na poddanie się im, biegły na nowo weryfikuje decyzję o wydaniu opinii zgodnie z zasadami wskazanymi w p. 1. Jeśli decyzja ta będzie pozytywna, biegły weryfikuje także plan przebiegu badań. Biegły nie może w pełnym zakresie wydać opinii dotyczącej osoby, która nie była przez niego bezpośrednio badana, a wszelkie potencjalnie formułowane na jej temat interpretacje mogą mieć jedynie charakter hipotetyczny, o czym biegły informuje sąd.

\section{Faza wprowadzajaca badania}

\subsection{Wstępne uzgodnienie planów i strategii badania z osobami badanymi}

Biegły kieruje do wszystkich badanych osób pismo zawierające informacje o czasie i miejscu oraz celu spotkania (spotkań), a także prośbę o ustosunkowanie się do tych propozycji w wypadku przeszkód lub o zgłoszenie wątpliwości. Biegły uzgadnia terminy także z osobami (instytucjami) odpowiedzialnymi za dowóz osób osadzonych w zakładach lub placówkach zamkniętych. Biegły może przekazać informacje o badaniach za pośrednictwem sądu.

3.2. Uzyskanie świadomej zgody na badanie (St. dgn. 1.11. i 1.12.) 
Biegły wyjaśnia osobie badanej cel badania, a także udziela informacji o czasie trwania, przebiegu badania i jego specyfice w taki sposób, by były dla niej zrozumiałe w zakresie, w jakim jest ona zdolna uczestniczyć świadomie w określonej sytuacji. Dotyczy to dorosłych i dzieci, w tym osób z dysfunkcjami poznawczymi. Osoby ponoszące koszty opinii powinny być o nich informowane przed rozpoczęciem badania. Biegły informuje także osoby badane, że gromadzony materiał jest archiwizowany i może podlegać interpretacji wyłącznie przez specjalistów. Nagrywanie lub kopiowanie w jakiejkolwiek formie czy też rozpowszechnianie przez badanych materiałów surowych jest niedopuszczalne. Dopiero po uzyskaniu świadomej zgody osoby badanej biegły przystępuje do badań.

3.3. Przedstawienie zasad kontaktu - uczciwości, zaufania i ograniczonej poufności

Biegły informuje, iż opinia będzie tym pełniejsza, im lepsza będzie wspótpraca i im więcej uzyska informacji przydatnych do rozstrzygnięcie problemów. Przekazując informacje o planowanym przebiegu badania, biegły przywiązuje szczególną wagę, aby nie wprowadzić w błąd osoby badanej ani nie być przez nią błędnie zrozumianą. Biegły wyjaśnia także, że kryterium przydatności jest jedynym, jakim kieruje się w selekcjonowaniu materiałów, co z jednej strony oznacza, że każda informacja, jakiej udziela badany, może się znaleźć w opinii, $\mathrm{z}$ drugiej zaś strony nie każda dostarczona przez niego informacja zostanie w opinii wykorzystana.

\section{Przebieg badań}

4.1. Realizowanie zadań zgodnie ze standardami

Biegły przeprowadza badania psychologiczne zgodnie z przyjętą wcześniej strategią diagnozowania i przewidzianą dla określonych narzędzi diagnostycznych procedurą (St. dgn. 3.1.). Biegły przykłada szczególną wagę do minimalizowania czynników zakłócających, zwłaszcza wynikających z interakcji z badanym (St. dgn. 3.3.) Niezbędny jest bezpośredni kontakt biegłego ze wszystkimi osobami badanymi.

4.2. Uwzględnianie dynamiki badania ( St. dgn. 3.1. i 3.2.)

Biegły może zmodyfikować hipotezy i strategię badania a także standardową procedurę, dostosowując je do postawy prezentowanej przez badanego lub do nowych, nieprzewidzianych okoliczności. Istotne diagnostycznie zmiany są odnotowywane, a następnie opisywane w opinii.

4.3. Podmiotowe traktowanie osób badanych (por. St. dgn. 3.2.)

W relacji z badanym biegły przestrzega zasad kodeksu etycznego psychologa, pamiętając o tym, że to na nim spoczywa odpowiedzialność za komfort psychiczny osób, o których wydaje opinię. Dotyczy to stanu psychicznego podmiotu nie tylko w trakcie badania, ale i po nim, w związku z jego konsekwencjami. Oznacza to dbałość o zachowanie zasady złotego środka - minimalizację potencjalnych, negatywnych $\mathrm{z}$ perspektywy badanego, przeżyć związanych $\mathrm{z}$ badaniem $\mathrm{i}$ informacjami zawartymi w opinii przy uwzględnieniu wszystkich tych danych, które badany świadomie udostępnił, a które są istotne dla rozstrzygnięcia 
problemu.

4.4. Nieprzekraczanie granicy wyznaczonej rolą biegłego

Psycholog występujący w roli biegłego nie podejmuje innych ról (mediatora, doradcy, terapeuty itp.) w relacji z badanym, ograniczając się do wskazówek dotyczących tego, do kogo i w jakim zakresie może się zwrócić badany.

\subsection{Zakres tematyczny badania}

Treści poruszane $\mathrm{w}$ badaniu są ściśle podporządkowane weryfikacji postawionych hipotez badawczych. Niemniej większość standardowych badań obejmuje istotne psychologicznie dane $\mathrm{z}$ historii życia osoby opiniowanej, podstawowe wymiary jej osobowości oraz informacje na temat jej zachowania w kontekście sytuacyjnym związanym z przedmiotową sprawą $\mathrm{i}$ w interakcjach $\mathrm{z}$ innymi osobami uwikłanymi w ten kontekst.

\subsection{Zakres stosowanych metod}

Narzędzia badawcze dobrane zgodnie ze standardem 2.4. w zdecydowanej większości badań obejmują: obserwację zachowania osoby badanej, wystandaryzowany, ujednolicony wywiad lub rozmowę psychologiczną, a ponadto testy i inne metody badania osobowości lub narzędzia specyficzne, np. ukierunkowane na badanie postaw, kompetencji wychowawczych itp. Są one dobrane w taki sposób, by stwarzały możliwość wzajemnego uzupełniania się i weryfikacji. Wyniki porównuje się z materiałami zawartymi w aktach sprawy i pochodzącymi $\mathrm{z}$ badania innych osób pozostających $\mathrm{w}$ ścisłej interakcji z badanym (jeśli takie materiały są dostępne). Wskazane jest, aby w przygotowanym zestawie znalazła się metoda, która pozwala na wielostronny opis osobowości, stwarzający tym samym możliwość poszerzenia zakresu hipotez badawczych.

Badane treści i narzędzia są dostosowane do roli osoby badanej w systemie rodzinnym. W zdecydowanej większości problemów sformułowanych przez sąd, wykorzystując poszczególne metody, biegły zmierza do ustalenia następujących informacji $\mathrm{w}$ badaniach poszczególnych osób:

\section{Rodzice (opiekunowie)}

1. Wywiad dotyczący badanego i strony przeciwnej

a) Dane formalne:

- możliwości w zakresie opieki i nadzoru nad dziećmi,

- warunki ekonomiczno-bytowe,

- stan zdrowia i funkcjonowania społecznego.

b) Ustalenie sytuacji rodzinnej:

- konflikty (obszary, nasilenie, forma, czas trwania, dynamika),

- stopień osobistego zaangażowania w opiekę nad dzieckiem,

- korzystanie z pomocy innych osób w opiece,

- obecność dziecka w sytuacjach konfliktowych. 
2. Obserwacja zachowania ukierunkowana na:

- spójność deklaracji werbalnych z zachowaniem,

- postawę wobec badania,

- więzi uczuciowe z dziećmi, postawy wobec nich i innych członków rodziny,

- behawioralne wskaźniki kompetencji wychowawczych.

3. Badania osobowości ukierunkowane na:

- determinanty kompetencji wychowawczych,

- podłoże i dynamikę występujących nieprawidłowości (trwałość, podatność na korektę, wgląd).

4. Integracja danych z wyżej wymienionych źródeł (zbieżności i rozbieżności informacji dostarczanych przez strony o sobie i uzyskane na ich temat od strony przeciwnej, a także na podstawie akt sprawy i wyników badań dzieci pod kątem całościowej oceny kompetencji wychowawczych).

Uwaga: Propozycja dotycząca zakresu diagnozy kandydatów na rodzinę adopcyjną znajduje się w załączniku nr 1 .

II. Dziecko

1. Rozmowa ukierunkowana na spostrzeganie:

a) każdego z rodziców:

- zaspokajania potrzeb rozwojowych (tu: więzi uczuciowych),

- umożliwiania kontaktu, swobodnego wyrażania uczuć i kształtowania postaw wobec drugiego opiekuna,

- roli w konflikcie z drugim opiekunem;

b) środowisk, jakie tworzą rodzice (w szczególności nowych partnerów rodziców, rodzeństwa oraz dzieci partnerów rodziców, dziadków itp.);

c) rodziny, problemów w niej występujących i gotowość otwartego wypowiadania się o nich;

d) potrzeb wobec otoczenia - kierowanych i zaspokajanych:

- rówieśników,

- dorosłych (w tym autorytetów),

- realizacji zadań związanych z wiekiem;

e) kwestii związanych z rozwojem własnym:

- zainteresowań i aspiracji,

- samooceny i jej adekwatności,

- kształtowania się norm,

- egzekwowania potrzeb i realizowania obowiązków.

2. Obserwacja (w tym podczas zabawy i w relacji z opiekunami).

3. Testy - ukierunkowane na weryfikację wszystkich wyżej wymienionych kwestii. 
III. Osoby współuczestniczące w wychowaniu

1. Wywiad ukierunkowany na:

- udział w opiece nad dzieckiem,

- możliwości w tym zakresie,

- rolę w życiu dziecka i więź uczuciową z nim,

- rolę w konflikcie między rodzicami.

2. Obserwacja zachowania (w tym, jeśli jest to możliwe, w interakcji z dzieckiem).

3. Badanie osobowości - w szczególnie uzasadnionych przypadkach.

\subsection{Zakończenie kontaktu z osobą badaną}

Na zakończenie kontaktu z osobą badaną biegły przekazuje jej wstępne refleksje dotyczące kierunku, w jakim zmierza diagnoza. Czyni to na tyle, na ile pozwala zgromadzony na tym etapie materiał, podkreślając, że analiza pełnego materiału może doprowadzić do istotnych modyfikacji opinii. Biegły informuje osoby badane kiedy, gdzie i na jakich warunkach uzyskają informacje o wynikach badania. Stara się ponadto załagodzić przewidywane niekorzystne konsekwencje spotkania nie tylko dla osoby badanej, ale również z jej strony w stosunku do innych osób (St. dgn. 1.12.).

\section{Analiza, interpretacja i integrowanie wyników}

\subsection{Podstawy selekcji}

Biegły analizuje i interpretuje zgromadzony materiał zgodnie ze standardami stosowania poszczególnych narzędzi. W integracji materiału uwzględnia konieczność jego selekcji z perspektywy użyteczności w rozstrzyganiu problemów sformułowanych przez zleceniodawcę (St. dgn. 4.1.).

\subsection{Weryfikacja danych}

Podstawę weryfikacji stanowi porównanie wszystkich uzyskanych wyników osoby badanej z pochodzącymi akt sprawy oraz - z badania innych osób - informacjami na temat występowania w jej historii życia określonych mechanizmów zachowania.

\subsection{Ocena prawdopodobieństwa wniosków końcowych}

Prawdopodobieństwo wniosków końcowych ocenia się na podstawie stopnia zaufania, z akim można przyjmować wyniki poszczególnych metod (St. dgn. 4.2. i 4.3.). Biegły uwzględnia czynniki zakłócające, które spowodowały odstępstwa od standardowej procedury badania.

\subsection{Treść integrowanego materiału}

Obszary integrowanego materiału odpowiadają obszarom badanych w opinii problemów i powinny być uporządkowane (od szczegółu do ogółu lub odwrotnie). W sprawach rodzinnych i opiekuńczych są to: ocena rozwoju fizycznego i psychicznego dziecka, ocena kompetencji wychowawczych rodziców oraz środowisk wychowawczych, które tworzą rodzice (por. załącznik 2). 


\subsection{Końcowe wnioski opinii}

Końcowe wnioski opinii powinny stanowić odpowiedź na postawione pytania badawcze. Jeśli nie jest to możliwe ze względów wskazanych w p. 1 standardów (przekraczanie kompetencji psychologa, brak wystarczających źródeł lub narzędzi do zweryfikowania postawionych hipotez), biegły w sposób przystępny wyjaśnia przyczyny sądowi. Warto rozważyć uwzględnienie wskazówek korekcyjnych i terapeutycznych, jeśli są one niezbędne do poprawy funkcjonowania systemu rodzinnego.

\section{Formulowanie opinii}

6.1. Spełnianie warunków formalnych

Podstawą przyjęcia opinii biegłych jest spełnianie przez nią warunków formalnych:

- wskazanie nazwisk i zakresu kompetencji biegłych, którzy sporządzili opinię, ich podpisów pod opinią; w wypadku instytucji także jej nazwę i podpis osoby kierującej instytucją potwierdzający spełnianie warunków formalnych;

- wymienienie dat badania i sporządzenia opinii, osób badanych (ze wskazaniem ich danych formalnych: wieku, wykształcenia, charakteru aktywności zawodowej) i pełnych nazw metod badawczych, które wobec nich zastosowano;

- przywołanie treści postanowienia skierowanego do biegłego, opracowanie części sprawozdawczej z badań pozwalającej na odtworzenie toku rozumowania biegłego (wszystkich istotnych rezultatów, które uzyskano w wyniku badania, a także interpretację głównych problemów badawczych ) i wniosków odpowiadających na tezy sformułowane w postanowieniu sądu.

\subsection{Przejrzystość i jasność}

Opinia powinna być sformułowana w sposób jasny i przejrzysty pod względem formy i treści. Oznacza to, że poszczególne części powinny być wyodrębnione adekwatnie do przedstawianych problemów i opatrzone tytułami, które odpowiadają ich zawartości.

6.3. Nieujawnianie wyników surowych i przeliczonych

Wyniki surowe i przeliczone poszczególnych narzędzi nie mogą być zamieszczane $\mathrm{w}$ opinii (St. dgn. 5.2.), gdyż łamie to standardy etyczne psychologa i może prowadzić do błędnych interpretacji dokonywanych przez osoby do tego nieprzygotowane zawodowo (strony w procesie, przedstawiciele wymiaru sprawiedliwości), co dla badanego może się okazać szkodliwe. Może też naruszać prawa autorskie wydawców poszczególnych narzędzi badawczych lub uniemożliwiać ponowne badanie.

\subsection{Sposób przedstawiania końcowej diagnozy osobom badanym}

Pisemna opinia biegłych stanowi podstawową formę informacji o uzyskanych wynikach, jakie osoba badana otrzymuje od biegłego za pośrednictwem organu zlecającego opinię, o czym biegły powiadomił osobę badaną w końcowym etapie spotkania, wskazując jednocześnie przybliżony termin dostarczenia opinii (por. St. 4.7.).

6.5. Rozdzielność informacji w opiniach kompleksowych 
Opinia opracowywana przez biegłych reprezentujących różne specjalności powinna być skonstruowana w taki sposób, aby było czytelne dla odbiorcy, za jakie sformułowania i za jakie wnioski opinii odpowiadają poszczególni specjaliści.

\subsection{Język opinii}

Treści opinii powinny być przekazywane w taki sposób, by były zrozumiałe dla odbiorcy, który nie jest specjalistą z dziedziny reprezentowanej przez biegłego, a zarazem oddawałyby tok rozumowania naukowego. Wszystkie niezbędne sformułowania specjalistyczne powinny zostać wyjaśniane, a w wypadku, kiedy jakieś pojęcie jest różnie definiowane lub jakieś zjawiska różnie interpretowane w różnych podejściach teoretycznych psychologii, wskazane jest podanie źródła lub teorii, do której odwołał się biegły.

\section{Opinia uzupetniająca (wystepowanie w sadzie)}

\subsection{Przygotowanie do wystąpienia w sądzie}

Przed udziałem w rozprawie biegły ponowne studiuje zawartość opinii pisemnej i odtwarza zawarty w niej tok rozumowania. Sprawdza także zawartość materiałów surowych, które stały się podstawą do sformułowanych interpretacji i wniosków. Biegły zapoznaje się z zarzutami (pytaniami, wątpliwościami) dotyczącymi opinii, jeśli takie zostały sformułowane.

\subsection{Uzupełnianie informacji}

Jeśli pytania zawarte w piśmie dołączonym do wezwania biegłego na rozprawę odnoszą się do nowego materiału dowodowego, biegły zapoznaje się $\mathrm{z}$ nim przed udziałem w rozprawie. Biegły gromadzi także informacje $\mathrm{z}$ zakresu wiedzy naukowej ułatwiające ustosunkowanie się do przedstawionych pytań lub zarzutów.

\subsection{Sprostowania nieścisłości i błędów}

W wypadku dostrzeżenia błędów formalnych lub merytorycznych w swojej opinii, bądź też w sytuacji, gdy nowo zgromadzone informacje stają się podstawą do zweryfikowania przedstawionej wcześniej opinii w części lub całości, biegły zmienia swoją opinię w tym zakresie.

\subsection{Zachowanie obiektywizmu}

Biegły kontroluje swoje emocje związane $z$ występowaniem na rozprawie i wykazuje należytą staranność o zachowanie obiektywnej, racjonalnej postawy wobec rozważanych wątpliwości. Wyraża swoje opinie zgodnie z zakresem zgromadzonych informacji, ustaleń diagnostycznych oraz stanem posiadanej wiedzy naukowej. 
Załącznik nr 1

Treść diagnozy w sprawach dotyczących przysposobienia powinna się koncentrować na następujących kwestiach:

1. Ocena jakości związku małżeńskiego badanych (w tym adekwatność oceny dokonywanej przez nich samych).

2. Określenie predyspozycji rodzicielskich badanych (a jeśli badani posiadają dzieci kompetencji wychowawczych).

3. Określenie systemu wartości, jakimi kandydaci kierują się w swoim życiu.

4. Określenie zasobów psychicznych kandydatów (w szczególności strategii radzenia sobie z sytuacjami trudnymi.

5. Określenie relacji interpersonalnych $\mathrm{z}$ otoczeniem.

Załącznik nr 2

1. Ocena rozwoju fizycznego i psychicznego dziecka:

- realizacja uzdolnień;

- przejawy zaniedbania, nadużyć, nieprawidłowości rozwojowych;

- ich źródła;

- więzi uczuciowe, potrzeby kierowane do rodziców (innych osób) i ich realizacja;

- postawa wobec konfliktu rodziców i gotowość do jej ujawniania;

- propozycje korygowania ewentualnych dysfunkcji.

2. Ocena kompetencji wychowawczych rodziców:

a) Wskaźniki behawioralne:

- wykorzystanie możliwości obiektywnych;

- stymulowanie potrzeb dziecka;

- sposób realizowania planów wychowawczych;

- kształtowanie relacji z drugim opiekunem.

b) Osobowościowe determinanty kompetencji wychowawczych:

- wskazanie trwałości deficytów i popełnianych błędów;

- możliwości i propozycje korekty.

3. Ocena środowisk wychowawczych:

- zakres udziału w wychowaniu;

- stymulowanie rozwoju dziecka;

- angażowanie dziecka w konflikt między rodzicami. 